\title{
HAKKAMA-VERB LAPSEKEELES: KAS ASPEKTILISUSE VÕI TULEVIKU TÄHISTAJA?
}

\author{
REILI ARGUS, \\ HELEN KÕRGESAAR
}

\begin{abstract}
Annotatsioon. Artiklis on vaatluse all hakkama-verbi kasutamine kahel eesti keelt omandaval eri vanuses lapsel. Spontaanse kõne materjalil põhineva analüüsi keskmes on oletus, et eesti lapsed väljendavad hakkama-verbiga esialgu pigem aspektilisust ehk sündmuse algusfaasi ning alles hiljem tulevikuaega. Analüüsitud keelematerjali (269 hakkama-verbi konstruktsiooni) põhjal selgus, et eesti laps kasutab hakkama-verbi esialgu ainult faasitähenduses ning alles neljandal eluaastal tekib tema keelde selliseid kasutusi, kus ta tähistab selle verbiga ka tulevikuaega.

Esialgu esineb lapse kõnes hakkama-verb ainult koos ateeliste tegevusverbidega, mis osutavad vajadusele ajas liigendamatut tegevust siiski hakkama-verbiga liigendada. Vanema lapse keelekasutusse lisanduvad lapse kasvades tulevikku tähistavad hakkama-verbi vormid, mis annavad märku sellest, et tulevikule viitamise vahendeid võib eesti laps omandadagi alles pärast neljandat eluaastat. Võtmesõnad: keeleomandamine, lapsekeel, tulevikuaeg, tegevuse algus
\end{abstract}

\section{Sissejuhatus}

Aja kui ühe põhilise kognitiivse kategooria omandamine saab enamasti alguse deiktilisest nullpunktist ,mina-siin-praegu” ning kuigi areng kulgeb kindlal suunal olevik-minevik-tulevik (Argus, Parm 2010), ei saa arenguetappe määrata ühe aja piiridega ning kitsalt kas grammatika ehk ajavormide või leksika ehk ajasõnadega. Olemasolevate andmete põhjal paistab, et oleviku ja mineviku eristamine ja minevikuvormide produktiivne kasutus areneb eesti lastel välja küllaltki vara, teise eluaasta lõpus, kuid tulevikutähenduse mõistmine ja tulevikku tähistavate keelendite loomine on keerukam ja võtab nagu paljude teiste keelte puhul (Clark 1998: 382) palju kauem aega. 
Eesti keeles grammatilist tulevikku verbikategooria näol ei ole. Üldiselt on ka teistes keeltes detailsemalt ja järjekindlamalt grammatiseeritud minevik kui olemasolev kogemus, tulevikust kõneldes pole grammatilise tulevikuvormi kasutamine nii reeglipärane. Tulevikutähendus kaasneb sageli mõne muu tegevust iseloomustava tähendusega, nagu modaaltähendused, aspektitähendus või veelgi kitsamalt, tegevuse alguse tähendus. (Comrie 1993: 44-45; Metslang 1994a: 538-539).

Eesti keele üks sagedasemaid tuleviku väljendamise vahendeid on faasiverb hakkama, mis toimib küll samamoodi kui tuleviku abiverb, kuid millel on samuti peale tulevikutähenduse veel teisigi, nt inhoatiivse aspekti ehk situatsiooni alguse tähendus. Kuna tulevikku väljendatakse eesti keeles ka olevikuvormide ja sündmuse ajalist lokalisatsiooni täpsustavate ajasõnadega, võimaldab just tuleviku omandamine vaadelda leksikaalsete ja (väheste) grammatiliste vahendite põimumist keeleomandamisprotsessis. Tuleviku omandamise võib ühelt poolt teha keerukaks see, et hakkamaverbi abil tuleviku väljendamiseks on vaja teatavaid süntaktilisi oskusi: ahelverb koosneb mitmest verbist, hakkama-verbist finiitvormis koos $m a$-infinitiiviga. Teisalt võib oletada, et tuleviku väljendamine on ka kognitiivselt keerukas, sest raske on tajuda aega, mille kohta lapsel veel kogemust ei ole. Kuna tulevik ei ole grammatiliselt ja leksikaalselt kuigi selgepiiriline kategooria (tulevikku saab väljendada nii ajasõnade kui ka eri konstruktsioonidega, sh saama-ja hakkama-verbiga, kusjuures hakkamaverbil on teisigi tähendusi peale tuleviku), võib selle omandamine toetuda kindlatele kinnistunud konstruktsioonidele suuremas osas kui mõne teise, kindlapiirilisema kategooria (nt minevik) omandamine.

Tulevikuaja omandamise kohta eesti keeles ei ole kuigi palju andmeid. On teada, et eesti lapsed hakkavad sündmushetke kõnehetkest ettepoole paigutama alates vanusest 2;01, mil nende keelekasutusse ilmub esmalt ajasõna pärast (Parm 2012). Eksperimentaalse metoodikaga saadud tulemused näitavad aga, et ühe sagedasema tuleviku väljendamise võimalusena kasutatava hakkama-verbiga väljendatavat tulevikuaega õpivad eesti lapsed olevikust eristama alles kuueaastaselt (Argus, Parm 2010: 38). Siinne kirjutis proovibki täiendada olemasolevaid andmeid ning kirjeldada kahe eri vanuses lapse pikiuuringuga saadud keelematerjali põhjal seda, kuidas eesti lapsed faasiverbi hakkama abil tuleviku tähistamist omandavad.

\footnotetext{
Laste vanust 2;7 tuleks lugeda 2 aastat ja 7 kuud.
} 
Hakkama-verbi omandamise käigu kirjelduse puhul on peamised uurimisküsimused järgmised.

1. Milliseid vahendeid kasutavad eesti keelt omandavad lapsed üldse tuleviku tähistamiseks ning kas need vahendid muutuvad lapse kasvades? Nt kuivõrd ja mille poolest erineb hakkama-verbi kasutus väikelapse (alla kolmeaastase) ja juba vanema, nt seitsme- või kümneaastase lapse kõnes?

2. Kas võib oletada, et nii nagu eesti keeles on hakkama-verbi algusetähendusest kasvanud välja tulevikutähendus (Metslang 1994a: 607), on ka lastel esimesed hakkama-verbi vormid kasutusel alguse tähenduses ja sellest kasvab välja tulevikutähendus ehk kas eesti lapsed kasutavad verbi hakkama rohkem alguse või tuleviku tähistamiseks ning kas võib samamoodi nagu mineviku omandamise puhul väita, et lapsed keskenduvad esialgu pigem aspektilisuse (Argus 2007) ja mitte niivõrd aja omandamisele?

3. Kuidas mõjutab tulevikuaja väljendamise omandamist see, et eesti keeles ei ole tuleviku puhul tegemist vormi ja pragmaatilise eesmärgi üksühese vastendusega (vastenduse mõiste kohta vt Bates, MacWhinney 1982), st et tulevikku saab väljendada mitmel moel, nt olevikus verbivormi ja ajasõnaga ning ka hakkama-verbiga, kuid samas on hakkama-verbil teisi tähendusi peale tuleviku?

4. Kas keelematerjalist on näha, et hakkama-verb esineb mingis kindlas leksikaalses ümbruses või kindlates grammatilistes konstruktsioonides, st kas selle verbi puhul on omandamise käigus märgata toetumist mõnele kindlale konstruktsioonile või mallile ehk õpimudelile?

\section{Kasutatud keelematerjal}

Kogutud keelematerjal hõlmab 19 tunni jagu spontaanse kõne lindistusi. Lindistatud on kaht last, kes omandavad eesti keelt esimese keelena, mõlemad lapsed on poisid. Andrease kõnet on lindistatud kokku 14 tundi lapse vanuses $1 ; 7-3 ; 0$ ning tegemist on pikiuuringu tarbeks kogutud igakuiste lindistustega. Teise poisi, Harley kõnet on lindistatud pisteliselt vanuses 4;0, 4;1, 7;2, 10;1 ja 11;0 tund aega korraga, kokku viis tundi. 
Spontaanse kõne lindistused on pärit CHILDES-i lastekeele andmepanga eesti lastekeele korpusest ${ }^{2}$.

Tulemuste tarbeks on analüüsitud nii lapse kui ka lapsevanema kõnes esinenud hakkama-verbi konstruktsioone, mis võimaldab muu hulgas vaadelda, millist sisendit, st nii hakkama-konstruktsioonide hulka kui ka nende esinemiskontekste, lapsele suunatud kõne omandamiseks pakub. Materjali on analüüsitud kahes etapis: esmalt on vaadeldud hakkama-verbiga lausungite esinemist kas tuleviku või tegevuse alguse tähistamisel, seejärel on peatutud ka hakkama-verbi konstruktsioonide vormilisel ehitusel ning ahelverbide koosseisus olevate verbide tähendusel.

\section{Verb hakkama verbide üldhulga taustal}

Andrease kõne lindistused võimaldavad jälgida hakkama-verbi kasutussagedust keeleomandamise varasel perioodil. Nagu tabelist 1 näha, ei ole hakkama-verb kuigi sage ei lapse ega ka vanema keelekasutuses. Kõnealuse verbi esinemisjuhtude sagedus ei ületa üheski lindistuses 7\% kõikidest verbisõnedest, kuid enamasti jääb see ühe protsendi piiresse. Kuigi lapse päris varases kõnes hakkama-verbi ei esine, leidub seda vähesel määral temale suunatud kõnes.

Nii nagu suureneb hakkama-verbi esinemus lapse ja vanema kõnes, suureneb ka selle verbi osakaal kõikide verbide hulgas. Kuna verb hakkama ei ole üldiselt kuigi sage, tulevad üksikute lindistuste situatsioonist johtuvad sageduse muutused väga selgelt esile, näiteks võib nii noorema kui ka vanema lapse kõne kuuajalise vahega tehtud lindistustes olla hakkamaverbi osakaal lindistussituatsiooni kõneainest tulenevalt küllaltki erinev (vt ka tabel 2).

2 Andrease alamkorpuse koostaja on Maigi Vija ning Harley alamkorpuse koostaja Helen Kõrgesaar, keelematerjal on kättesaadav aadressil http://childes.psy.cmu. edu/data/Other/Estonian/. 
Tabel 1. Hakkama-verbi osakaal kõikide verbisõnede hulgas lapse kõnes ja lapsele suunatud kõnes: Andreas

\begin{tabular}{|c|c|c|c|c|c|c|}
\hline & \multicolumn{3}{|c|}{ Lapse kõne } & \multicolumn{3}{c|}{ Lapsele suunatud kõne } \\
\hline $\begin{array}{c}\text { Lapse } \\
\text { vanus }\end{array}$ & $\begin{array}{c}\text { Hakkama- } \\
\text { verbi } \\
\text { esinemus } \\
\text { kordades }\end{array}$ & $\begin{array}{c}\text { Verbi- } \\
\text { sõnede } \\
\text { üldhulk }\end{array}$ & $\begin{array}{c}\text { Hakkama- } \\
\text { verbi osakaal } \\
\text { verbisõnede } \\
\text { üldhulgas } \\
\text { protsentides }\end{array}$ & $\begin{array}{c}\text { Hakkama- } \\
\text { verbi } \\
\text { esinemus } \\
\text { kordades }\end{array}$ & $\begin{array}{c}\text { Verbi- } \\
\text { sõnede } \\
\text { üldhulk } \\
\text { verbi osakaal } \\
\text { verbisõnede } \\
\text { üldhulgas } \\
\text { protsentides }\end{array}$ \\
\hline $1 ; 7$ & 0 & 0 & 0 & 2 & 424 & 0,5 \\
\hline $1 ; 8$ & 0 & 25 & 0 & 0 & 283 & 0 \\
\hline $1 ; 9$ & 0 & 33 & 0 & 2 & 294 & 0,7 \\
\hline $1 ; 10$ & 0 & 135 & 0 & 1 & 718 & 0,1 \\
\hline $1 ; 11$ & 0 & 50 & 0 & 1 & 138 & 0,7 \\
\hline $2 ; 0$ & 2 & 287 & 0,7 & 7 & 522 & 1,3 \\
\hline $2 ; 1$ & 15 & 219 & 6,8 & 4 & 381 & 1 \\
\hline $2 ; 3$ & 3 & 219 & 1,37 & 1 & 157 & 0,6 \\
\hline $2 ; 4$ & 0 & 344 & 0 & 1 & 203 & 0,5 \\
\hline $2 ; 5$ & 7 & 135 & 5,2 & 0 & 151 & 0 \\
\hline $2 ; 6$ & 2 & 122 & 1,6 & 4 & 259 & 1,5 \\
\hline $2 ; 7$ & 0 & 444 & 0 & 1 & 284 & 0,3 \\
\hline $2 ; 8$ & 3 & 313 & 0,9 & 0 & 208 & 0 \\
\hline $3 ; 0$ & 11 & 515 & 2,1 & 7 & 486 & 1,4 \\
\hline $3 ; 1$ & 12 & 545 & 2,9 & 7 & 335 & 2,1 \\
\hline
\end{tabular}

Tabel 2. Hakkama-verbi osakaal kõikide verbisõnede hulgas lapse kõnes ja lapsele suunatud kõnes: Harley

\begin{tabular}{|c|c|c|c|c|c|c|}
\hline & \multicolumn{3}{|c|}{ Lapse kõne } & \multicolumn{3}{c|}{ Lapsele suunatud kõne } \\
\hline $\begin{array}{c}\text { Lapse } \\
\text { vanus }\end{array}$ & $\begin{array}{c}\text { Hakkama- } \\
\text { verbi } \\
\text { esinemus } \\
\text { kordades }\end{array}$ & $\begin{array}{c}\text { Verbi- } \\
\text { sõnede } \\
\text { üldhulk }\end{array}$ & $\begin{array}{c}\text { Hakkama- } \\
\text { verbi osakaal } \\
\text { verbisõnede } \\
\text { üldhulgas } \\
\text { protsentides }\end{array}$ & $\begin{array}{c}\text { Hakkama- } \\
\text { verbi } \\
\text { esinemus } \\
\text { kordades }\end{array}$ & $\begin{array}{c}\text { Verbi- } \\
\text { sõnede } \\
\text { üldhulk }\end{array}$ & $\begin{array}{c}\text { verbi osakaal } \\
\text { verbisõnede } \\
\text { üldhulgas } \\
\text { protsentides }\end{array}$ \\
\hline $4 ; 0$ & 3 & 182 & 1,6 & 12 & 494 & 2,4 \\
\hline $4 ; 1$ & 1 & 110 & 0,9 & 5 & 356 & 1,4 \\
\hline $7 ; 1$ & 20 & 676 & 2,9 & 14 & 567 & 2,5 \\
\hline $10 ; 2$ & 8 & 555 & 2,4 & 9 & 609 & 1,5 \\
\hline $11 ; 0$ & 14 & 495 & 2,8 & 2 & 206 & 1 \\
\hline
\end{tabular}


Vanema lapse, Harley kõne lindistused võimaldavad heita pilgu hilisemale keelelisele arengule lapse eri vanuses. Üldiselt hakkama-verbi esinemus lapse kasvades küll mõnevõrra suureneb, kuid olulisel määral alles 7 aasta ja 1 kuu vanuse lapse dialoogis. Vanema kõnes on kõnealust verbi samuti rohkem kui väiksemale lapsele suunatud kõnes (vrd tabeliga 1), kuid mitte rohkem kui 2,5\% kõikidest verbisõnedest.

Seega võib oletada, et hakkama-verbi puhul ongi tegemist verbiga, mida kasutatakse rohkem vanema lapsega suheldes, kuid mille kasutussagedus jääb siiski paari-kolme protsendi piiresse kõikidest verbidest.

\section{Kas alguses aspekt ehk tegevuse algus või aeg ehk tulevik?}

Ajasüsteemi omandamine on sageli (Weist 1986) jagatud neljaks perioodiks. Omandamine algab deiktilisest nullpunktist ehk süsteemist, kus kõnehetk, sündmushetk ja vaatlushetk on sama. Seejärel areneb välja sündmuse aja ja kõnehetke eristus, nt lauses Jaan sõi eile kõik maasikad ära, ning sel perioodil tähistavad lapse minevikuvormid eelkõige perfektiivset tegevust. Esialgse sündmuse ja kõnehetke lahknemise järel hakkab laps paigutama sündmusi ka kõnehetkest ettepoole ning ajasüsteemi areng jõuab kolmandasse perioodi ${ }^{3}$. Vaatlushetke eristus tekib samuti sel perioodil, kui laps suudab esialgu vaatlushetke kõnehetkest eristada adverbide ja ajalausete abil, nt lauses Pärast tööd läheb isa poodi. Alles seejärel areneb tavaliselt välja täiskasvanupärane ehk vaba ajasüsteem, kus nii vaatlushetk, kõnehetk kui ka sündmushetk võivad paikneda ajas erinevalt, nt Pärast seda kui isa poest tuleb, peab ta asjad külmkappi tõstma (Weist 1986: 357).

Kui esimest arenguperioodi iseloomustab ainult olevikuvormide kasutus, siis teisel perioodil ilmuvad lapse kõnesse ka esimesed minevikuvormid, millel on enamasti selge aspektiline väärtus (vt nt Antinucci, Miller 1976: 167; eesti keele kohta Argus 2007: 28). Faasiverbi hakkama omandamist silmas pidades on kõige olulisem aga areng alates teisest perioodist, kui on tekkinud kõnehetke eristus sündmushetkest ning laps hakkab sündmusi paigutama ka kõnehetkest ettepoole. Nii võib samamoodi nagu mineviku omandamise puhul oletada, et kui esialgu tähistab laps esimeste minevikuvormidega lõpetatud tegevust, tähistab

3 Richard Weisti järgi (1986: 367) algab teine faas tavaliselt kolmanda eluaasta alguses ning kolmas pärast lapse kolmeaastaseks saamist. 
ta esimeste hakkama-verbi vormidega samuti aspektilisust ehk tegevuse algusfaasi (nt hakkame kohvi jooma ehk alustame kohvijoomist - tegevuse alguspunkt on määratud kõnehetkega). Hakkama-verbi preesensivormid võivad alles hiljem hakata tähistama aega ehk tulevikku (hakkan hästi óppima - tegevuse alguspunkt ei ole määratud). Näiteks on vene keele tuleviku omandamise kohta väitnud Maria Polinsky (2007), et varases keeleomandamise faasis ei vali lapsed aja grammatilisi väljendusvõimalusi lihtsalt seepärast, sest aspekt pakub ise olukohase ajalise tõlgenduse: imperfektiivsel aspektil (ateeline) on pragmaatiline tõlgendus nü̈̈ ja siin, perfektiivne (teeline) aspekt on tõlgendatav kui eelnev. See omakorda seletab Polinsky arvates, miks omandatakse tulevik hilja - vene keeles ei ole lihtsalt tulevikuvormi, mis pakuks pragmaatilist (ehk siis aspektilist) tõlgendust (Polinsky 2007: 18).

Algust märkiva ja tulevikulise hakkama-verbi kasutuse eristuse kohta märgib Helle Metslang, et tulevikuline tõlgendus on võimalik eelkõige sel juhul, kui viidatakse pikemale ajavahemikule, punktuaalne paigutus ajas aga toob enamasti kaasa alguse tõlgenduse domineerimise tulevikulise tõlgenduse üle (Metslang 1994a: 607, 1994b: 167). Metslangi väitel on tulevikuline kasutus kujunenud välja just tegevuse algust tähistavast kasutusest (Metslang 1994a: 607, 1994b: 167).

Selgitamaks, millist tähendust laps keeleomandamisel hakkamaverbiga varem või rohkem väljendab, on kontekstile toetudes kõik kõnealust verbi sisaldavad lausungid jagatud kas algust või tulevikku tähistavateks. Liigituse aluseks on kõigepealt jaotus mineviku- ja olevikuvormis kasutuste vahel, kusjuures minevikuvormis hakkama-verb tähistab alati tegevuse algust.

${ }^{*} \mathrm{CHI}^{4}$ : tuluke hakkas põlema. (Andreas vanuses 2;1)

Olevikuvormis kasutuste puhul aitab tuleviku- ja faasitähendust eristada kas ajamäärus või kontekst, näiteks toob ajamääruse homme kasutus esiplaanile tulevikutähenduse, kuid ajamääruse nüüd kasutus enamasti faasitähenduse.

*MOT: nüüd hakkab Antsu [: Andreas] hakkab nüüd masseerima, eksole.

$4 * \mathrm{CHI}=$ laps; $* \mathrm{MOT}=\mathrm{ema} ; \% \mathrm{com}=$ tegevuse kommentaar; $* \mathrm{OBS}=$ vaatleja; $\#=$ väike paus. 
Samas võib mõnel teisel juhul olla nüüd kasutusel pigem partiklina ja konteksti põhjal on esiplaanil hoopis tulevikutähendus.

\%com: ema ja laps ehitavad toolidest onni.

*MOT: kes seal nüüd magama hakkab siis?

*CHI: ei hakka keegi, ma \# me panime lihtsalt. (Andreas vanuses 3;1)

Eelmises näites ei viita ema sellele, et keegi alustab onnis magamist, vaid pigem realiseerub habituaalne hakkama-verbi tähendus ja mõeldakse, et kui onn saab valmis, saab sellest kellegi magamiskoht. Nn kontrollkriteeriumina kasutati algusetähenduse puhul parafraseerimist ehk kui lausung oli võimalik ilma tähendusmuutuseta ümber sõnastada konstruktsiooni alustab millegi tegemist abil, liigitati see algust tähistavate hulka.

Esmalt ilmneb, et eesti laps alustab sündmuste paigutamist kõnehetkest ettepoole leksikaalsete vahenditega ehk ajasõnadega. Kuigi esimesed hakkama-verbi vormid on Andrease kõnes registreeritud juba vanuses 2;0 ja esimesed tulevikule viitavad ajasõnad kohe, varsti, homme ilmuvad vaatlusaluse lapse kõnesse vanuses $2 ; 3^{5}$, nt tuleb varsti mondionu [= remondionu], ei ole esimeste hakkama-verbi kasutuste puhul tegemist selgelt tuleviku tähistamisega.

Andrease esimeste hakkama-verbi sisaldavate lausungite puhul ei ole nende liigitamine algust või tulevikku tähistavaks kogu olemasoleva konteksti põhjal üheselt võimalik. Esimeses hakkama-verbiga näites ei ole üldse selge, mida kõnealune verb lapse keeles tähendab.

\%com: kallab mänguasjakasti põrandale.

*CHI: kosta [: korstnast] suitsu.

*MOT: mis suitsu?

*CHI: akame [: hakkame] \# maha suits.

Teise samas lindistuses esineva hakkama-verbi puhul tuleb kõne alla nii tuleviku kui ka alguse tõlgendus, sest laps võib viidata sellele, et millalgi tulevikus tahab ta hakata kohvi jooma (st mängima emaga kohvijoomist), samahästi võib aga mitteverbaalse tegevuse taustal (laps sätib parasjagu mängunõusid lauale) tulla kõne alla ka alguse tõlgendus. Kõige enam tuleb aga lausungis esile hortatiivne ehk üleskutsuv tähendus.

5 Mainimist väärib aga ka asjaolu, et alla kaheaastase lapsega vanemad tulevikule viitavaid ajasõnu peaaegu ei kasutagi ning nende hulk kasvab alates lapse vanusest 2;3 järsult (Parm 2012). Ülevaate Andrease ajasõnade omandamisest annab Sirli Parm artiklis „Ajasõnad varasel perioodil eesti lapsekeeles” (Parm 2012). 
*CHI: hakame [: hakkame] kohvi jooma ka.

Hakkama-verbi hortatiivset kasutust aga üllatuslikult Andrease keelematerjalis rohkem ei leidugi, samuti puuduvad need vanema lapse keelematerjalis. Selgelt tegevuse algust tähistavad hakkama-verbiga konstruktsioonid ilmuvad Andrease kõnesse vanuses 2;1, siis on ühes lindistuses kõnealust verbi sisaldavaid lausungeid koguni 15, mis kõik tähistavad tegevuse algust ja on enamikus minevikuvormis.

*CHI: (h)akkas lindistama nüüd.

\%com: vaatab diktofoni.

*CHI: (h)akkas pelema [: põlema].

\%com: diktofoni tuluke põleb.

Esimene ja kogu materjalis ainus selgelt tulevikku märkiv hakkamaverbiga konstruktsioon leidus lapse kõnes vanuses 3;1.

Joonis 1 annab ülevaate lapse kõnes ja lapsele suunatud kõnes esinevate hakkama-verbi konstruktsioonide jaotumusest algust ja tulevikku tähistavateks. Ilmekalt on näha, et lapse kõnes tulevikku tähistavaid hakkama-verbi konstruktsioone enne vanust 3;1 ei esinegi, lapsele suunatud kõnes üksikuid küll leidub, kuid tunduvalt vähem kui tegevuse algust tähistavaid konstruktsioone. Kuna materjali hulk ei ole suur ja siinkohal on tegemist kokku ainult kolme esinemisjuhuga, ei saa seetõttu kindlalt väita, et varasel keeleomandamise perioodil kasutab vanem tuleviku väljendamiseks pigem hakkama-verbi kui ajasõnu.
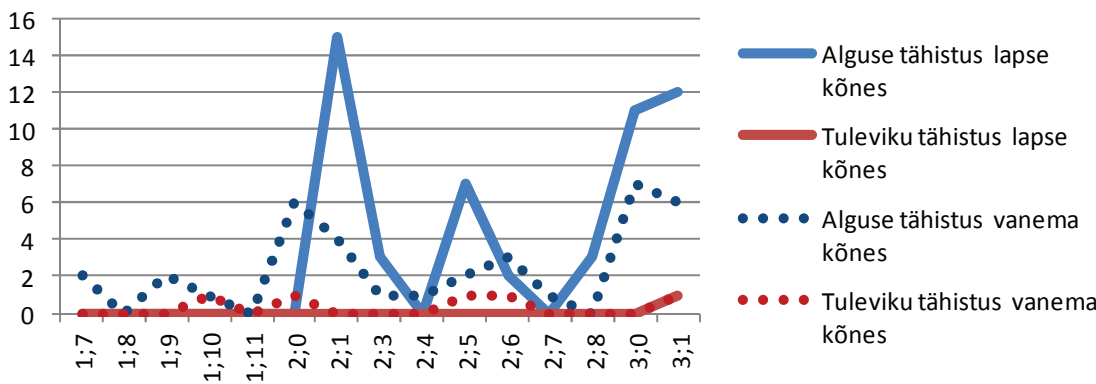

Joonis 1. Hakkama-verbi kasutamine kas tegevuse alguse või tuleviku väljendamiseks Andrease kõne lindistustes 
Vanema lapse, Harley kõnes on samuti rohkem tegevuse algust kui tulevikku tähistavaid hakkama-verbi konstruktsioone (vt joonis 2).

*CHI: ... ja siis võtsid väiksed koerad ära akkasid [: hakkasid] kohe sööma Võrreldes noorema lapse ja temale suunatud keelekasutusega torkab silma, et ka vanema lapse keelekasutuses on rohkem algust tähistavaid konstruktsioone kui temaga rääkiva täiskasvanu omas. Tulevikku tähistavaid konstruktsioone küll vanema lapse kõnes leidub, nt

*OBS: mis sa teed seal esimeses klassis igav akkab [: hakkab] ju sedasi.

*CHI: ei hakka,

kuid nende hulk sõltub suuresti konkreetsest lindistussituatsioonist.

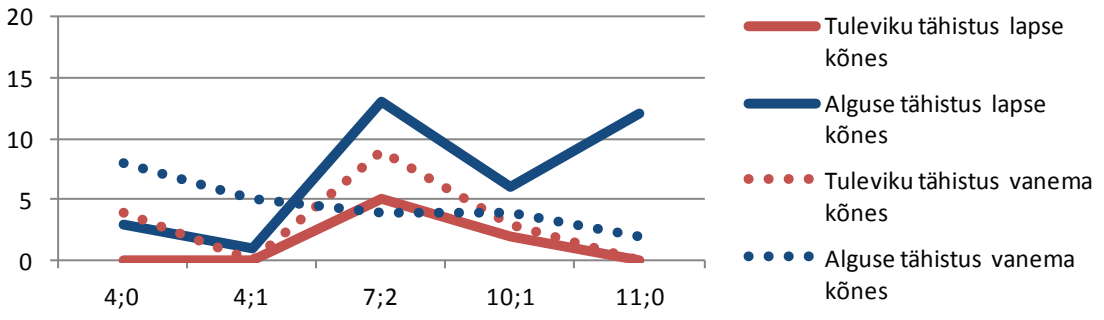

Joonis 2. Hakkama-verbi kasutamine kas tegevuse alguse või tuleviku väljendamiseks Harley kõne lindistustes

Näiteks räägitakse ühes (lapse vanuses 7;2) lindistatud dialoogis sellest, et laps läheb varsti kooli, ning just selles lindistuses esineb nii ema kui ka lapse kõnes palju tuleviku väljendamiseks kasutatud hakkama-verbi konstruktsioone.

*MOT: mis sa tegema hakkad koolis?

*MOT: hakkad hästi õppima.

Tähelepanu väärib veel asjaolu, et kui vanema lapse kõnes ebamäärase tõlgendusega (Metslang 1994b: 607) hakkama-verbi konstruktsioone ei leidunud, siis lapsevanema kõnest võib mõne sellise siiski registreerida.

\%com: isa ja laps joonistavad kahekesi ralliraja ja teevad seal võidusõitu. Hudson Hornet on autode multifilmi tegelane (auto).

*OBS: ja Hudson hakkab järele jõudma. (Harley vanuses 11;0) 
Kokkuvõtlikult saab hakkama-verbi kohta väita, et laps tähistab esialgu selle verbiga selgelt ainult tegevuse algust, tulevikutähendus ilmub tema kõnesse pea aasta pärast algusetähendust. Vanema lapse kõnes on kõnealust verbi tuleviku tähenduses küll rohkem, kuid sagedasem paistab ka seal olema aspektilisuse väljendamine ehk algusetähendus.

\section{Kas õpimudel ehk kindel leksikaalne ja grammatiline ümbrus või produktiivne kasutus?}

Elena Lieveni jt (1997: 187) väitel moodustavad mingid kindla leksikaalse koostisega mallid alla kolmeaastaste laste lausungitest ligikaudu 60\%. Eesti keele omandamise puhul on märgatud suuremat toetumist kindlatele leksikaalsetele mallidele just nendes keelesüsteemi osades, mis on keerukamad, nt täissihitise vormi valik (Argus 2009). Kuna hakkama-verbiga on lapsel võimalik väljendada nii algust kui ka tulevikku ning teisalt on alguse- ja tulevikutähenduse väljendamiseks teisigi võimalusi, võib oletada, et sellise mõnevõrra hägusa keelesüsteemi osa omandamisel vajab laps enam tuge mingist kindlast leksikaalsest ümbrusest või kinnistunud mallist.

Hakkama-verb on Andrease kõnes ja talle suunatud kõnes kasutusel enamasti ahelverbi koosseisus ${ }^{6}$, materjalis leidub ainult mõni näide, kus kõnealune verb esineb lihtverbina tähenduses 'algama' .

*CHI: hakkab lastesaade. $(2 ; 5)$

*CHI: hakkab a tähega. $(3 ; 0)$

Vaadeldes lapse varaseid hakkama-verbi kasutusi, ilmneb, et vanuses 2;1, mil lapse kõne tunniajases lindistuses leidus hakkama-verbi 15 korda, oli laps seda kombineerinud kaheksa eri verbiga. Seega ei saa väita, et sel perioodil esineks hakkama koos ainult mõne kindla üksiku verbiga. Ka hilisemates lindistustes võib küll leiduda ühe ja sama verbiga kombinatsioone, kuid tegemist ei ole ei sõnajärjelt ega leksikaalselt sisult kinnistunud mallidega.

${ }^{*} \mathrm{CHI}$ : hakkame minema (teise tuppa). $(3 ; 1)$

kuid:

${ }^{*}$ CHI: hakkan voodisse minema. $(3 ; 1)$

6 Ka Piret Piiroja tulemustest ilmneb, et XX sajandi kirjakeelekorpuse materjalis on verb hakkama ahelverbi koosseisus 88\% juhtudel (Piiroja 2010: 42). 
Andrease keelematerjalist ilmneb, et ahelverbis kombineeruvad verbiga hakkama üldjuhul tegevust väljendavad verbid, nt hakkab rääkima, põlema, limpsima, haigutama, lindistama, laulma, masseerima, koristama, ravima. Neist ainult rääkima-verb on Piret Piiroja esitatud sagedasemate hakkama-verbiga ahelverbe moodustavate verbide hulgas (Piiroja 2010: 44). Vanuses 2;1 registreeritud 15-st hakkama-verbiga moodustatud ahelverbist oli laps kasutanud teelist verbi ainult ühel korral (hakkas kaela panema), kokku leidus teelist verbi sisaldavaid konstruktsioone materjalis kõigest kolmel korral.

Vanema lapse puhul on märgata, et hakkama-verbiga ahelverbides on ühelt poolt ülekaalus küll tegevusverbid, nt hakkas nutma (Harley vanuses 4;0), hakkas köhima, sööma, jagama, laulma (vanuses 7;2), aga samas leidub järjest rohkem ka seisundi- ja tunnetusverbe, nagu hakkab kurvastama, magama, meeldima, rõõmustama (vanuses 7;2), mis noorema lapse keelematerjalis puudusid. Hiljem lisandub ka üksikuid teelisi verbe, nt hakkad pöörama (ringi) (Harley vanuses 7;2) või hakatakse vahetama (vanuses 11;0).

Asjaolu, et hakkama-verb esineb kõige sagedamini just ateeliste verbidega, viitab vajadusele selliseid lõpp-punktita ja ühtlaselt kulgevaid tegevusi ning seisundeid ajas täpsemalt liigendada. Tegevuse algust tähistav hakkama-verb annabki lapsele selle võimaluse.

Vaadeldes hakkama-verbi sisaldavate konstruktsioonide vormilist ehitust, ilmneb, et kui ajavormidest leidus varases keeleomandamise faasis küll rohkem olevikuvormi, esineb ka minevikuvormi küllaltki vara, juba 2 aasta 1 kuu vanuse lapse keelematerjalis (nt hakkas lindistama nü̈̈d). Koguhulgalt moodustavad minevikuvormid ligi neljandiku kõikidest hakkama-verbi kasutusjuhtudest.

Verb hakkama esineb omandamise algusjärgus lapse kõnes enamasti küll kolmandas pöördes, nt hakkas lindistama nüüd (Andreas vanuses 2;1), kuid samas leidub ka varasel omandamisperioodil mõni ainsuse esimese pöörde vorm. Mitmuse esimese pöörde vormid lisanduvad lapse keelekasutusse vanuses 3;0. Vanema lapse, Harley hakkama-verbi vormivalik on küll rikkalikum, kuid domineerivaks on ikkagi ainsuse kolmandas pöördes esinevad ahelverbid, nt hakkas sõitma (Harley vanuses 7;2). Vanuse kasvades paistab suurenevat ka minevikuvormide kasutus ning vanema lapse kõnes moodustavadki minevikuvormid kõikidest hakkama-verbi esinemise juhtudest pea poole. Võib oletada, et vanem laps kasutas sage- 
damini minevikuvorme, kuna ta jutustas lindistatud dialoogides lugusid, kirjeldas juhtumeid, mida oli ise kogenud, telerist näinud, raamatust lugenud. Võib oletada, et vanemal lapsel on juba olemas mingi kogemus, mis nooremal puudub, seetõttu suurenebki mingis vanuses üldiseltki minevikuvormide hulk.

\section{Kokkuvõtteks}

Tuleviku tähistamine algab eesti keelt omandaval lapsel leksikaalsete vahenditega ehk ajasõnadega. Samal perioodil, kolmanda eluaasta alguses, kasutab laps hakkama-verbi ühendeid väljendamaks aspektilisust ehk tegevuse algust, mitte veel aega. Nii nagu eesti keeles on hakkama-verbi algusetähendusest kasvanud välja tulevikutähendus, on ka lastel esimesed hakkama-verbi konstruktsioonid kasutusel alguse tähenduses ja sellest kasvab alles hiljem välja tulevikutähendus. Ilmselt mängib hakkama-verbi tulevikutähenduse hilise kasutuse alguse puhul oma rolli ka see, et tavaliselt väljendatakse hakkama-tulevikuga regulaarselt toimuvaid, korduvaid tegevusi ning lapsel lihtsalt puudub sageli pragmaatiline vajadus sellistele olukordadele viidata.

Esialgu on neis hakkama-verbi sisaldavais konstruktsioonides kasutusel ainult ateelised tegevusverbid, hiljem lisanduvad ka seisundid ja alles seejärel muutub verbivalik laiemaks ning lapse kasvades lisandub ka üksikuid teelisi verbe. Samas ei ole ka varases keeleomandamise faasis märgata, et hakkama-verb esineks kitsalt ühes konkreetses aja- või pöördevormis või mingis kindlas leksikaalses ümbruses. Seega ei saa väita, et hakkama-verbi omandamisel toetuks laps mingile kindlale kinnistunud leksikaalsele või positsioonilisele mallile, pigem loob ta hakkama-verbi konstruktsioone produktiivselt.

Tuleviku väljendamiseks oskab laps hakkama-verbi kasutada ilmselt alles pärast neljanda eluaasta algust. Tulevikutähenduses kasutatud hakkama-verbi esinemuse suurenemine vanema vaadeldud lapse keelematerjalis annab tunnistust sellest, et kõik keelevahendid ei ole kolmandaks eluaastaks omandatud ning lapse keeleline areng toimub veel nelja- ja seitsmeaastaseltki. 


\section{Kirjandus}

Antinucci, Francesco, Ruth Miller 1976. How children talk about what happened. - Journal of Child Language 3, 167-189. http://dx.doi.org/10.1017/ S0305000900001434.

Argus, Reili 2007. Eesti keele verbi ajamorfoloogia ja aspektilisuse omandamisest. - Emakeele Seltsi aastaraamat 52 (2006). Peatoim. Mati Erelt. Tallinn: Teaduste Akadeemia Kirjastus, 7-32.

Argus, Reili 2009. Psühholingvistiline katse eesti keele objekti käändevahelduse omandamise uurimise meetodina. - Emakeele Seltsi aastaraamat 54 (2008). Peatoim. Mati Erelt. Tallinn: Teaduste Akadeemia Kirjastus, 22-43.

Argus, Reili, Sirli Parm 2010. Eesti keele ajakategooria omandamisest - ajavormid ja ajasõnad. - Eesti Rakenduslingvistika Ühingu aastaraamat 6. Toim. Helle Metslang, Margit Langemets, Maria-Maren Sepper. Tallinn: Eesti Keele Sihtasutus, 25-41. http://dx.doi.org/10.5128/ERYa6.02

Bates, Elizabeth, Brian MacWhinney 1982. Functionalist approaches to grammar. - Language Acquisition: The State of the Art. Ed. Eric Wanner, Lila R. Gleitman. Cambridge/Mass.: Cambridge University Press, 173-218.

Clark, Eve V. 1998. Morphology in language acquisition. - The Handbook of Morphology. Ed. Andrew Spencer, Arnold M. Zwicky, Oxford: Blackwell, 374-389.

Comrie, Bernard 1993. Tense. Cambridge Textbooks in Linguistics. Cambridge: Cambridge University Press.

Lieven jt 1997 = Elena V. M. Lieven, Julian M. Pine, Gillian Baldwin. Lexicallybased learning and early grammatical development. - Journal of Child Language 24 (1), 187-219. http://dx.doi.org/10.1017/S0305000996002930.

Metslang, Helle 1994a. Eesti ja soome - futuurumita keeled? - Keel ja Kirjandus 9, 534-547.

Metslang, Helle 1994b. Eesti ja soome - futuurumita keeled? - Keel ja Kirjandus $10,603-616$.

Parm, Sirli, 2012. Ajasõnad varasel perioodil eesti lapsekeeles. - Eesti Rakenduslingvistika Ühingu aastaraamat 8. Toim. Helle Metslang, Margit Langemets, Maria-Maren Sepper. Tallinn: Eesti Rakenduslingvistika Ühing,195-212. http://dx.doi.org/10.5128/ERYa8.13.

Piiroja, Piret 2010. Verb hakkama situatsiooni alguse väljendajana eesti keele ahelverbides. Magistritöö Tartu Ülikooli eesti ja üldkeeleteaduse instituudis.

Polinsky, Maria 2007. Acquisition of Russian: Uninterrupted and Incomplete Scenarios. - The Slavic, East European, Language Resource in Language; http://seelrc.org/glossos/ The Slavic and East European Language Research Center glossos@seelrc.org (02.03.2012).

Weist, Richard 1986. Tense and aspect. - Language acquisition: studies in first language development. Ed. Paul Fletcher, Michael Garman. Cambridge, $356-374$. 


\title{
Hakkama-verb in child language: a marker of aspectuality or future?
}

\author{
Reili Argus, \\ Helen Kõrgesaar
}

In Estonian one of the most frequent means of expressing the future is the phase verb hakkama 'begin', which acts similarly to a future auxiliary; however, in addition to the future, it has several other meanings, such as the inchoative aspect or the beginning of a situation. Because in Estonian the future is expressed also by the present forms and temporal words that specify the temporal localization of an event, the acquisition of the future enables us to observe the entwinement of lexical and grammatical devices in the acquisition process.

The article focuses on spontaneous speech of two differently-aged children (the material of the younger child represents the age 1;7-3;0 and that of the older child $4 ; 0,4 ; 1,7 ; 2,10 ; 1$ and $11 ; 0)$. The purpose of the study was to find out whether for an Estonian child the hakkama-verb expresses the future or aspectuality, that is, the beginning phase of an action rather than the future. The study analysed constructions with hakkama-verbs in the speech of both the child and the caregiver, which allowed to observe the kind of input that parental speech offers to the child with regard to both the number of hakkama-verbs and their occurrence contexts.

The occurrence frequency of this verb does not exceed in any recordings 7 per cent of all verb tokens, but usually it is about one per cent. Constructions with the hakkama-verb that clearly denote the beginning of an action emerged in the speech of the younger child at the age of $2 ; 1$; the first and the only construction with the hakkama-verb that clearly expressed the future occurred in the child's speech at the age of 3;1. It is apparent that the child's speech did not reveal any hakkama-verbs denoting the future before the age of 3;1; in fact, child-directed speech revealed some, but they occurred much less frequently than the hakkamaverbs denoting the beginning of an action. To sum up, one can claim in respect of the hakkama-verb that a child clearly uses it at first only to express the beginning of an action; the future sense emerged almost a year after the sense of beginning. It is true that the speech of the older child revealed more instances of this verb with a future sense, but the meaning of aspectuality or the meaning of beginning seems to be more frequent there, too.

At first the constructions with the hakkama-verb include only atelic action verbs, followed by states, and only then the range of verbs becomes wider, and occasional telic verbs emerge as the child grows. At the same time, during the 
early phase of language acquisition the hakkama-verb does not occur only in a single tense or person or in some specific lexical environment. Thus, one cannot claim that in the acquisition of the hakkama-verb the child follows some lexical or positional pattern; rather, he or she creates productively constructions with the hakkama-verb.

It appeared that a child is able to use the hakkama-verb for the expression of the future as late as after the beginning of the age of four. An increase in the number of the hakkama-verbs in the speech of the older child shows that not all linguistic devices have been acquired by the age of three, and that the linguistic development of a child will continue also at the age of four and seven.

Keywords: language acquisition, child language, future, inchoative aspect

Reili Argus

eesti keele ja kultuuri instituut

Tallinna Ülikool

Narva mnt 25

10120 Tallinn

reili.argus@tlu.ee

Helen Kõrgesaar

eesti keele ja kultuuri instituut

Tallinna Ülikool

Narva mnt 25

10120 Tallinn

helen.korgesaar@gmail.com 